\title{
Motifs of Narrative Structure of Sacred Tombs in Surabaya
}

\author{
Sudarwati \\ Faculty of Letters \\ 17 Agustus University \\ Surabaya, Indonesia \\ tyadandion@yahoo.com
}

\author{
Anik Cahyaning Rahayu \\ Faculty of Letters \\ 17 Agustus University \\ Surabaya, Indonesia \\ Novi Andari \\ Faculty of Letters \\ 17 Agustus University \\ Surabaya, Indonesia
}

\begin{abstract}
The sacred tomb is a kind of legend which contains semi-historical stories describing the actions of heroes, population movements, and the creation of local customs. The study of narrative motifs was conducted to investigate typology of folklore: its origin, acculturation, and metamorphosis (Alan Dundes in [1, p. 116]). Reasearch on the origin of the sacred tombs in Surabaya aims at collecting and classifying motifs on historical typology of its existence. This study adopts Spradley's ethnography method for data collection and text construction, and qualitative descriptive method for analysis of the narrative motifs or typology. This study found three narrative structure motifs. The first motif is that the deceased were historical figures in past kingdom, God's messegers, and local community figures. The second motif is that the theme of the narrative represents the figures as religious heroes who fought against spiritual darkness, Islamic prechers, pioneers of new settlements. In relation to the second motif, the third motif is that the figures are endowed with supernatural power and charisma in their missions that their tombs are considered sacred.
\end{abstract} motif

Keywords-folklore; legend; sacred tomb; narrative structure

\section{INTRODUCTION}

Oral tradition is related to anthropology because it deals with society and culture in a certain area. It cannot also be separated from history since tradition is inherited from generation to generation. Accordingly oral tradition relates to the history of an area.

Anthropology deals with the human life and products. Oral tradition is the human product inherited from generation to generation which results in tradition shaping certain behavior of society who believe it. Anthropology and oral tradition are related to history dealing with the origin of the occurrence of something believed by people until now. Anthropology, oral tradition, and history are related to each since the three of them form an identity of people group.

Every group of people in the world has folklore that can be classified into oral tradition [2, p. 5]. Folklore is usually in the form of a short narration derived from oral tradition from one generation to the next one and changes as well as addition happen to it. This is the characteristic of folklore which develops in society with many varieties. [3, p. 189]. Far more important to the state project of appropriating folklore was the Organization for Public Instruction [4, p. 515].

The result of the previous research on Mapping and Classification of Surabayan Folklore shows that Surabayan folklores are dominated with legends. Legend is folk history, or a story which is believed to have really happened [5, p. 52]. The kind of legend found in Surabaya consists of legend of sacred tomb, the origin of statue, the origin of village, river, and mountain. The most findings are the legend of sacred tombs. Therefore, it is interesting to focus on making deeper study on this kind of legend.

Legend is based on story. Interpretation of a process results in an action for people who believe it. According to Foster in Nurgiyantoro [6, p. 143], story is a narration of events constructed based on time sequences. Thus, it can be concluded that a story is the order of events which is reconstructed based on real events. The element of plot is something done by or happens to characters of story [6, p. 144]. Besides the element of character, there are also element of setting, theme, and the others.

Oral tradition about the origin of sacred tombs in Surabaya has not been written specifically. However, from searching through internet, it is found that stories about sacred tombs are written in the form of articles and shared in internet by observers. This relates to what Hutomo says that the switching process of oral literature to the written one takes place individually because this is enjoyed by individuals [7, p. 3].

The important thing seen from research on folklore as oral tradition is the process and the result of utterance. The oral process result of folklore is transformed into the written text whose elements can be researched. Indriyani says that the transformation of folklore from oral to written will cause changes [8, p. 4]. Sweeney adds that transformation can make the oral story become tighter and compact [9]. 
Folklore can be analyzed by using structural approach. As mentioned before that oral tradition is related to anthropology and history. Structuralism covers many aspects dealing with human social phenomena, one of which is pure social sciences, like Anthropology, Sociology, Politics, Economics, and Psychology as well as humanity sciences such as Literature, History, and Linguistics. According to Structuralism, all social activity manifestation is structure.

What becomes the basis of structural analysis is the relation among parts unifying totality. Dundes in Endraswara [1, p. 112] says that folklore has structure consisting elements which relate one another. The most important element is motif which can be divided into some motifems which construct the unity of meaning. Transforming oral folklore to written text aims at making structural analysis process and finding the motif easier. Structural analysis of motif is so far used to analyze fairy tales.

McKean and Allan Dundes has developed text structure analysis to find the typology of a story. Mckean has combined Dundes' structural analysis and diffusion historical method and Olrix's epic law theory to analyze fairy tale of Kancil, which result in the finding of motifem. From many versions of fairy tale of Kancil, McKean found 6 motifems.

According to Allan Dundes, analysis of narrative structure motif is focused on meaning and function. This analysis will result in the understanding of typology and the origin of folklore, the changes, acculturation, and metamorphosis. Besides having diffusion historical meaning, this analysis is also used to explain specific meaning of a story.

According to Dorson, folklore structure of a story needs to be explored in order to get some points as follows. The first is type and motif. Every story has typology or motif to be conveyed, such as honesty, justice, etc. The second is framework or form applied by the narrator and how the narrator relates it with situation, such as being sad, humorous, pleasant, etc. The third is figure of speech that is the beauty of story related to certain values, such wisdom, horror, etc. The fourth is formulaic verbal sequences such as monologue, narrator's comment, and dialogue stereotype. The fifth point is repetition of certain passage and sequences. This means that in connecting, raising, ending the story, and so forth, whether the author uses repetition or not [1, p. 116].

The analysis to find the motif done by Mckean and Alan Dundes above can be applied to other types of folklore, in this case legend. Dundes says that analysis of narrative structural motif is done to learn about the typology and the origin of folklore. Two keywords above are assumed to exist in other kinds of folklore.

The findings of legends of sacred tombs in Surabaya can be analyzed by using the analysis of narrative structural motif to find the typology of the story.

\section{RESEARCH METHOD}

This study is an ethnographic study using a method developed by James P. Spradley [10]. There are twelve steps used. They are (1) setting informants, (2) interviewing informants, (3) making ethnographic notes, (4) asking descriptive questions, (5) analyzing the result of interview, (6) making domain analysis, (7) asking structural questions, (8) making taxonomic analysis, (9) asking contrast questions, (10) making component analysis, (11) finding cultural themes, and (12) writing an ethnography.

Then the research is continued by using descriptive method because this research uses participant observation. It means that the researchers are involved in the data collection. Then they understand, analyze, and continuously classify the data.

Surabaya has five areas, namely Central, East, West, North, and South Surabaya. Therefore, the informants used are 70 people. The selected informants are those who really know the folklore. The informants are the elders of the area or caretakers (if the story is the origin of a tomb). The average age of informants who are all male is 55-65 years.

\section{DisCUSSION AND RESULT}

The story of sacred tombs is categorized as legend because there is the history of the sacred tomb origin. Not all tombs are considered sacred by society. Tomb is funeral where the deceased are buried. The word sacred means being holy and being able to provide something out of common human ability because of his or her loyalty and devotion to God (about the pious person). It also means being holy and magical which can give magical and psychological effects on others (about thing or holy place) [11].

Therefore, a tomb is called sacred if the deceased buried in the tomb someone who had charisma in society when he was alive. Accordingly, his or her tomb can give magical effect on other people to have a better life.

Weber in Johnson says that charisma is someone's superiority [12, p. 229]. Veeger adds that charisma is applied to one's personality which differs him from common people because he or she is given extraordinary authority or ability [13, p. 182]. Weber also says that charismatic person is usually treated specially and exceptionally in society because he is considered to be endowed with authority which can exemplify normative and moral commitment. One example given by Weber is a religious leader or preacher as a charismatic person who tends to be obeyed and imitated by his or her followers. Originally a figure of folklore gained prominence as a artistic figure, where in this form has commonly been interpreted as definite influence on a round social community [14, p. 261]. The figures always have main strands in mythology surrounding them [15, p. 106]. Their tombs are often visited by people who have various purposes and motivations, like looking for blessing, strength, status, popularity, long life, wealth, happiness, and the others. The power of spiritual values in the eyes of pilgrims as what makes them continue to go places that are considered sacred [16, p. 452].

After analyzing 72 legends of sacred tombs in Surabaya, typology or motifs found can be categorized as follows.

- A figure endowed with supernatural power who is able to fight disavowal and help surrounding people;

- An Islamic figure spreading Islamic teachings and exemplifying good behavior to surrounding people; 
- A figure having bravery to fight against colonialism as well as other crimes;

- A generous figure who always exemplifies good act and sacrifices his or her wealth for other people;

- A figure who helps to develop life skill for society;

- A figure who becomes a pioneer of new settlement.

The findings of motifs in Surabaya sacred tombs are elaborated below.

\section{1) Figures Endowed With Supernatural Power}

\section{a) Mbah Wijil}

He has supernatural power to fight against the interference of king of jinn. His sacred tomb is in Ketintang.

\section{b) Habib Neon}

The figure whose tomb is in Sidodadi also has supernatural power. His body can glow when he is in the darkness.

\section{c) Ki Ageng Pengging}

He is buried in Ngagel. His supernatural power makes him unable to be stabbed with kris except in his point of weakness, his elbow.

\section{d) Ki Ageng Brondong}

The figure whose tomb is in Pegirikan is endowed with supernatural power that he is still alive even though he does not eat and drink while drifting in the sea for months.

\section{e) Joko Kuti}

His tomb is in Kutisari. His supernatural power is that he can fight against the interference of jinn troops.

\section{f) Mbah Bolong or Sonhaji}

He is able to determine the qibla direction by making a hole on the wall.

\section{g) Sawunggaling} troops.

His supernatural power enables him to kill Netherlands

\section{h) Joko Jumput}

He has supernatural power, which enables him to defeat Prince Situbondo.

\section{2) Figures Spreading Islamic Teachings}

\section{a) Mbah Wijil}

He spreads Islamic teachings by showing an example to pray actively and recite Qur'an.

\section{b) Sayyid Ali Asghor}

As the son of Sayyid Ali Akbar, this figure also a preacher spreading Islam.

\section{c) Habib Neon}

He is a well-known Islamic leader giving a good example in praying and bersholawat.

\section{d) Ki Ageng pengging}

Besides spreading Islamic teachings, he is known as a leader for people unity without differentiating people from different religion.

\section{e) Mbah Buyut Tondo}

This figure is a preacher who is in charge of spreading Islam in Central Surabaya.

\section{f) Mbah Ratu}

This Chinese Islamic leader has spread Islam through all parts of Indonesia.

g) Abah Toyyib

In spreading Islamic teachings, he gives example of praying compulsory and non compulsory prayers, and fasting actively until the end of his life.

\section{h) Kya Ageng Brondong}

He is a charismatic Islamic leader spreading Islamic teachings by showing his being very religious, faithful, and kind.

i) Raden Endang Kamulyaan

Her ability to recite and understand Qu'ran supports her to spread Islam.

\section{j) Mbah Karimah} Islam.

Kembang Kuning is the place where this figure spreads

\section{k) Mbah Bungkul}

Bungkul is Mbah Bungkul's area to teach Islam to people.

l) Mbah Kendar Syaiban

The same as Mbah Bungkul, this figure's area for spreading Islam is also Bungkul area.

\section{m) Sunan Ampel}

Like his nick name, Sunan Ampel, this figure is successful to teach and spread Islam in Ampel. As one of walisongo, Sunan Ampel is regarded a sacred figure who has an important role in the spread of Islam though peaceful way. The pilgrims still expect blessing even though he has passed away their toms are will maintained and visited by many people around [17, p. 603].

n) Sayyid Sedo Masjid

Surabaya Kingdom is the place where he spreads Islamic teachings.
o) Kyai Haji Hasbullah and Syech Sumbawa
p) Mbah Abdulrrahman
q) Habib Umar Thoha Al Rusawa

\section{3) Brave Figures}

a) Mbah Wijil

He is brave to fight against the king of jinn and Netherlands troops.

b) Sayyid Ali Asghor

He has bravery to fight against Netherlands.

c) Ki Ageng Pengging

His bravery can be seen when he fights against Demak Government since his being Moslem is considered to be against the government.

\section{d) Mbah Ratu}

He is an admiral of war who is very brave to wade through the ocean. 


\section{e) Joko Kuti}

He is known to be brave to fight agains jinn troops.

\section{f) Sawunggaling}

He is brave enough to fight against Netherlands troops and jinn troops when clearing up the forest Nambas Kelingan.

\section{g) Eyang Kudo Kardono}

Because of his bravery, he becomes a Majapahit warlord who crushes Kuti rebellion.

\section{4) Generous Figures}

\section{a) Habib Neon} the poor.

He is a generous person who is willing to socialize with

\section{b) Ki Ageng Pengging}

His generosity can be seen when he likes socializing with society and he never differentiates people's social status.

\section{c) Abbah Toyyip}

This generous figure likes giving his wealth to others needing it.

\section{d) Mbah Buyut Sambongan}

His generosity makes him grant his land for others' settlement.

\section{5) Figures of Life Skill Education}

a) Abah Toyyib

Besides a religious leader, this figure also spreads his ability relating to life skill, such as, agricultural, business, etc.

\section{b) Mbah Ratu}

Besides as an admiral of war, and a sailor, he can also teach people about agricultural, farms, fishery, and carpentry.

\section{c) Sunan Ampel}

He teaches a philosophy, Mo Limo which is very good to be applied by society.

\section{6) Figures Becoming Pioneers of New Settlements}

a) Mbah Buyut Sambongan

He grants his land for people settlement.

b) Mbah Buyut Tondo

He is believed as a pioneer of new settlement in Ketandan.

c) Joko Kuti

He is believed to be the first person together with his wife Siti Karomah who has built Kutisari settlements.

\section{d) Mbah Buyut Canting}

He is the pioneer of Kedurus settlement.

e) Sunan Ampel

This figure is a well-known pioneer of new settlement in Ampel and Kembang Kuning.

\section{f) Mbah Sima dan Mbah Sumbersari}

These figures are the pioneers of settlement in Tuban.

\section{g) Sawunggaling}

He becomes the pioneer of new settlement in the forest Nambas Kelingan.

h) Gusti Wongsi Negoro

This figure is the pioneer of new settlement in Bangkingan.

\section{CONCLUSION}

After analyzing the sacred tombs in Surabaya, a conclusion can be drawn as follows.

- The legends of sacred tombs are included in folklore relating to anthropology and history. These sacred tombs form society's identity because tombs being sacred are the result of people's evaluation and cause people's action and treatment towards the tombs.

- The legends of sacred tombs in Surabaya can be analyzed by using narrative structure motif study by McKean and Alan Dunden. From the analysis, typology or motifs of the origin of sacred tombs are found.

- The motifs of the legends of sacred tombs found in the research can be categorized into 6 types: (1) figure endowed with supernatural power, (2) Islamic figure spreading Islamic teachings, (3) figure having bravery, (4) generous figure, (5) figure helping to develop life skill for society, and (6) figure becoming a pioneer of new settlement.

\section{REFERENCES}

[1] S. Endraswara, Seksologi Jawa [Javanese Sexology]. Yogyakarta: Pustaka Widyatama, 2009.

[2] J. Danandjaja, Foklor Indonesia: Ilmu Gosip, Dongeng, dan lain-lain [Indonesian Folklore: Gossip Knowledge, Fairytale, et cetera]. Jakarta: Grafiti, 1991.

[3] H. C. Holman, A Handbook to Literature. Indianapolis: Bobbs Merrill Educational Publishing, 1980.

[4] F. Vejdani, "Appropriating The Masses: Folklore Studies Ethnography and Interwar Iranian Nationalism,” Int. J. Middle East Stud., vol. 44, pp. 507-526, 2012. DOI: 10.1017/S002074381200044.

[5] J. Danandjaja, Folklor Indonesia [Indonesian Folklore]. Jakarta: Grafiti, 2002.

[6] B. Nurgiyantoro, Teori Pengkajian Fiksi [Fiction Studying Theories]. Yogyakarta: Gadjah Mada University Press, 2015.

[7] S. S. Hutomo, Mutiara yang Terlupakan: Pengantar Sastra Lisan [The Forgotten Diamond: Oral Literary Introduction]. Surabaya: Penerbit HISKI Jawa Timur, 1991.

[8] R. Indriyani, "Cerita rakyat Jawa dalam Suatu Upaya Pelestarian [Javanese Tales in a Preservation Effort]," presented in Kongres Bahasa Jawa [Javanese Language Congress]. Semarang: Panitia Kongres, 1991.

[9] A. Sweeney, A Full Hearing. Berkeley: University of California Press, 1987.

[10] J. P. Spradley, Metode Etnografi [Ethnography Methods], 2nd ed. Yogyakarta: Tiara Wacana, 2007.

[11] Ministry of Education and Culture of the Republic of Indonesia, "The Great Dictionary of Indonesian Language - Search,” [Online]. Available: kbbi.kemdikbud.go.id. 
[12] D. P. Johnson, Teori Sosiologi Klasik dan Modern [Theories of Classical and Modern Sociology]. Jakarta: PT. Gramedia, 1986.

[13] K. J. Veeger, Realitas Sosial [Social Reality]. Jakarta: PT. Gramedia, 1993.

[14] G. Forth, “Images of the Wildman Inside and Outside Europe,” Folklore, vol. 118, pp. 261-281, December 2007.
[15] K. Strassler, "Seeing the Unseen in Indonesia's Public Sphere: Photograpic Appearances of a Spirit Queen,” Compar. Stud. in Socie. and Hist., vol. 53, no. 1, pp. 98-130, 2014. DOI: 10.1017/S0010417513000637.

[16] Marwoto, "Spiritual Phenomena in the Town of Demak," Procedia-Soc. and Behav. Sci., vol. 227, pp. 451-457, 2016.

[17] A. S. Budiarto, Indriastjario, and A. B. Sardjono, "The Urban Heritage of Masjid Sunan Ampel Surabaya, toward the Intelligent Urbanism Development,” Procedia - Soc. and Behav. Sci., vol. 227, pp. 600-608, 2016. 